\title{
PROCESS MODEL FOR ORGANISATIONAL CHANGE: A STUDY OF ESTONIAN COMPANIES
}

\author{
Ruth Alas \\ Estonian Business School \\ Lauteri 3, Tallinn 10114, Estonia \\ Ruth.alas@ebs.ee \\ Received 5 February 2004; accepted 12 April 2004
}

\begin{abstract}
Both the popular press and academic literature tend to consider organizational change as a step-by-step process leading to success. This paper examines the suitability of the theory that guides the implementation of change at company level for organisations in countries in transition. The author's survey, conducted in 137 Estonian companies, shows that the main focus of Estonian managers has been on initiating change and much less attention paid to assessing the process of change and making modifications and consolidating improvements. Although attention has been focused on initiating change, nobody has mentioned having identified any resistance to change. Based on the survey results the author proposes a change model for Estonian organisations.
\end{abstract}

Keywords: Organisational change, Process of change, Resistance to change, Overcoming resistance, Unlearning, Transformation.

\section{Introduction}

In Western Europe and the United States, organisational change has been an object of systematic research for the last six decades. Interest in evaluating organizational change dates from the early 1960s [1]. The universal challenge that change proposes is to learn how organizations and employees can change faster than the changing business conditions in order to become more competitive [2].

On the whole, transformational changes are currently taking place in countries in transition, where systematic research in this area is rare and there are no commonly accepted theories about change worked out for these countries.

Estonia has already passed through two big waves of change. The first was at the end of the eighties and beginning of the nineties, when socialism was replaced by capitalism. The market was empty and it was quite easy to start a company and be successful. In the second half of nineties the market became saturated. A lot of small enterprises went bankrupt and others started to merge. The economic crisis in Asia also had a negative impact on our fast-growing infant economy. Now Estonia faces a new challenge: that of being successful in reframing the institutions needed for member states of the European Union. In its current stage of development, Estonia is still struggling with basic levels of welfare, where survival needs dominate [3]. In order to reach the level of developed countries, there is still a lot to be done. The whole economy, including all organisations, has to cope with the constant implementation of change. Successful overall transition from the former socialist economy requires performance improvement at the enterprise level [4]. Even more, Liuhto's [ibid] research results in Estonian organisations suggest that environmental stability should be integrated into the discussion and elaborated into environmental determinants and managerial voluntarism.

Jick [5] has generalized that both the popular press and academic literature tend to consider organizational change as a step-by-step process leading to success. The research question that arises is the suitability of existing theories that guide the implementation of 
change at the company level for organisations in Eastern Europe, which are forced to implement change more quickly in an environment similar to chaos.

In this paper, a brief overview of Western theories about the process of change will be followed by an analysis of research results in Estonian organisations. Based on the survey results the author will propose a change model for Estonian organisations.

\section{Theories about change}

Change management can be viewed as an analytical, educational (learning) and political process [6]. To understand how organizations change, management scholars have borrowed many concepts from such disciplines as child development, evolutionary biology and others. Van de Ven and Poole [7] proposed four distinct views of the organisational change process: evolutionary, dialectic, life cycle and teleological. From among these four types of process models, one has gained more attention from scholars of organisational studies-goal-driven teleological change. In this case the driving force is the desired stage and the process consists of stating the aim, planning and implementing the change. We can say that this is a strategically planned change.

Bennis [8] highlights a difference between theories of change and theories of changing. Theories of change are suitable only for observers of social change, not for participants in, or practitioners of. They don't talk about matters of directing or implementing change.

Armenakis and Bedeian [9] divide research on organizational change into the following types:

- Content research attempts to define factors that influence the change process such as strategy, structure and systems. Content research relates these factors to organizational effectiveness.

- Contextual research addresses forces or conditions existing in an organizations external and internal environment.

- Process research focuses on actions undertaken during the enactment of an intended change.

- Criterion research deals with outcomes commonly assessed in an organizational change effort.

Porras and Robertson [10] identified two types of organizational development theories: change process theory and implementation theory. Change process theories attempt to explain the dynamics through which organizations or groups or individuals change. Implementation theory is more oriented toward practice and focuses on intervention activities needed to carry out effective planned change.

As former socialist countries need to implement change quickly, they cannot wait for evolutionary developments. Based on this expectation, the author has chosen some aspects from these cited theories that suit the former socialist countries. From Van de Ven and Poole [7] as for Western countries teleology is the most suitable. From the study by Armenakis and Bedeian [9], features of contextual and process research should be combined. From Porras and Robertson [10] implementation theory is more suitable, because of the need for intervention and a more active approach to change. This forms the basis for a deeper review of the literature - the author now turns her attention principally to theories concerning the process of change.

\section{Models of the change process}

The basic model was developed by Kurt Lewin. Lewin's [11] model consisted of three steps: unfreezing, moving, and refreezing. Lewin's model is often quoted, but sometimes without the warning that freezing at the new level should be a deliberate planned objective. Merely reaching a new level is no guarantee of its permanency, even in the short term [12].

Mohrman and Cummings's [13] self-design change strategy is described, as with Lewin's model, in three stages:

1. Laying the foundation. This includes acquiring knowledge, valuing and diagnosing. Valuing means determining the corporate values that will be needed to implement the corporate strategy. Diagnosing shows what needs to be changed to enact the corporate strategy and values.

2. Designing. The parameters of a new organization are specified. The specifics are left to be tailored to the lower levels of organization.

3. Implementing and assessing. This includes an ongoing cycle: changing structures and behaviours, assessing the process and making modifications.

The implementation and assessment activities may lead back to first step.

Tichy and Devanna [14] have also used three steps:

1. Recognizing the need for change.

2. Creating vision.

3. Institutionalizing the change. 
There are also five and six steps models. Cummings and Worley [15] developed a model that identifies the next activities needed to facilitate change at the individual, group and organizational level:

1. Motivating change, which includes creating a readiness for change and overcoming any resistance to change.

2. Creating a vision.

3. Developing political support: assessing the change agent's power, identifying and influencing key stakeholders.

4. Managing the transition: activity planning, commitment planning and management structures.

5. Sustaining momentum. This means providing resources for change, building a support system for the change agents, developing new competences and skills and reinforcing new behaviour.

Judson [16] describes five phases as following:

1. Analysing and planning the change.

2. Communicating the change.

3. Gaining acceptance of new behaviours.

4. Changing from the status quo to a desired state.

5. Consolidating and institutionalizing the new state.

By Goss, Pascale, and Athos [17] reinvention is not changing what is, but creating what isn't. The steps taken are as follows:

1. Assembling a critical mass of key stakeholders.

2. Doing an organizational audit.

3. Creating urgency and discussing the undiscussable, because any threat that everyone perceives and no one discusses hurts the company much more than a threat that is clearly revealed.

4. Harnessing contention. To cope with variety externally, the system must encourage and incorporate variety internally. Although conflict has human and organizational costs, it is essential fuel for self-questioning and revitalization.

5. Engineering organizational breakdowns. When an organization sets out to reinvent itself, breakdowns should happen by design rather than by accident.

Using survey evidence from patterns of success, Greiner [18] divided the change process into six phases, each of them broken down into their particular stimulus and reaction, which appear to be critical for moving the power structure from one phase to another. These phases are as follows:
1. Pressure on top management.

2. Intervention at the top.

3. Diagnosis of problem.

4. Invention of new solutions.

5. Experimentation with new solutions.

6. Reinforcement of positive results.

According to Beer, Eisenstat and Spector [19] there are six important steps for effective change:

1. Mobilize commitment to change through joint diagnosis of business problems.

2. Develop a shared vision of how to organize and manage for competitiveness.

3. Foster consensus for the new vision, competence to enact it, and cohesion to move it along.

4. Spread revitalization to all departments without pushing it from the top.

5. Institutionalize revitalization through formal policies, systems, and structures.

6. Monitor and adjust strategies in response to problems in the revitalization process.

The most popular change process model was developed by Kotter [20], who sees eight phases in the change process:

1. Establishing a sense of urgency by relating external environmental realities to real and potential crises and opportunities facing an organization.

2. Forming a powerful coalition of individuals who can rally others to support the effort. Encouraging the group to work together as a team.

3. Creating a vision to help direct the change effort and developing strategies for achieving that vision.

4. Communicating the vision through numerous communication channels.

5. Empowering others to act on the vision by changing structures, systems, and procedures that seriously undermine the vision in ways that will facilitate implementation.

6. Planning and creating short-term wins and building momentum for continued change.

7. Consolidating improvements and producing still more change. Changing such structures, systems, procedures, and policies that aren't consistent with the vision.

8. Institutionalizing the new approaches by articulating connections between the change effort and organizational success. Developing the means to ensure leadership development and succession.

Galpin [21] views the change process as a wheel with 
Table 1. A comparison of models for the organisational change process

\begin{tabular}{|c|c|c|c|}
\hline Lewin (1989) & Unfreezing & Moving & Re-freezing \\
\hline $\begin{array}{l}\text { Mohrman's and } \\
\text { Cummings's (1989) }\end{array}$ & Laying the foundation/ Designing & Implementing and assessing & \\
\hline Tichy and Devanna (1986) & $\begin{array}{l}\text { Recognizing need for change } \\
\text { /Creating vision }\end{array}$ & & Institutionalizing change \\
\hline $\begin{array}{l}\text { Cummings and Worley } \\
\text { (1993) }\end{array}$ & $\begin{array}{l}\text { Motivating change/Creating a } \\
\text { vision/Developing political support }\end{array}$ & Managing the transition & Sustaining momentum \\
\hline Judson (1991) & $\begin{array}{l}\text { Analysing and planning the } \\
\text { change/Communicating the } \\
\text { change/Gaining acceptance of new } \\
\text { behaviours }\end{array}$ & $\begin{array}{l}\text { Changing from the status quo to a } \\
\text { desired state }\end{array}$ & $\begin{array}{l}\text { Consolidating and } \\
\text { institutionalising the new } \\
\text { state }\end{array}$ \\
\hline $\begin{array}{l}\text { Goss, Pascale, Athos } \\
\text { (1998) }\end{array}$ & $\begin{array}{l}\text { Assembling a critical mass of key } \\
\text { stakeholders/Doing an organisational } \\
\text { audit/Creating urgency }\end{array}$ & Harnessing contention & $\begin{array}{l}\text { Engineering organisational } \\
\text { breakdowns }\end{array}$ \\
\hline Greiner (1975) & $\begin{array}{l}\text { Pressure on top } \\
\text { management/Intervention at the } \\
\text { top/Diagnosis of problems }\end{array}$ & $\begin{array}{l}\text { Invention of new solutions } \\
\text { /Experimentation with new solutions }\end{array}$ & $\begin{array}{l}\text { Reinforcement of positive } \\
\text { results }\end{array}$ \\
\hline $\begin{array}{l}\text { Beer, Eisenstat and Spector } \\
\text { (1990) }\end{array}$ & $\begin{array}{l}\text { Mobilise commitment/Develop a } \\
\text { shared vision/Foster consensus }\end{array}$ & Spread revitalisation & $\begin{array}{l}\text { Institutionalise } \\
\text { revitalisation/Monitor and } \\
\text { adjust strategies }\end{array}$ \\
\hline Kotter (1998) & $\begin{array}{l}\text { Establishing a sense of } \\
\text { urgency/Forming a powerful } \\
\text { coalition/Creating a vision/ } \\
\text { Communicating the vision }\end{array}$ & $\begin{array}{l}\text { Empowering/Short-term wins } \\
\text { /Consolidating improvements }\end{array}$ & $\begin{array}{l}\text { Institutionalising the new } \\
\text { approaches }\end{array}$ \\
\hline Galpin (1996) & $\begin{array}{l}\text { Establishing the need for } \\
\text { change/Developing a vision } \\
\text { /Diagnosing and analysing the } \\
\text { current situation/Generating } \\
\text { recommendations }\end{array}$ & $\begin{array}{l}\text { Detailing the recommendations /Pilot } \\
\text { testing the recommendations } \\
\text { /Preparing the recommendations for } \\
\text { rollout/Rolling out the } \\
\text { recommendations }\end{array}$ & $\begin{array}{l}\text { Measuring, reinforcing, and } \\
\text { refining the change }\end{array}$ \\
\hline
\end{tabular}

nine wedges. These wedges are as follows:

1. Establishing the need for change.

2. Developing and disseminating a vision of a planned change.

3. Diagnosing and analyzing the current situation.

4. Generating recommendations.

5. Detailing the recommendations.

6. Pilot testing the recommendations.

7. Preparing the recommendations for rollout.

8. Rolling out the recommendations.

9. Measuring, reinforcing, and refining the change.

The author compared these theories about the process of change from different theorists and found that all these theories could be compared with Lewin's [11] three-step model (Table 1).

Comparisons indicate that the theorists had turned most of their attention to Lewin's first step-preparing for the change. The crucial questions are: how to establish the need for change, how to motivate employees, and how to mobilize commitment to change.

\section{Resistance to change and overcoming resistance}

According to Lawrence [22] most of the resistance that occurs is unnecessary. However, this argument ignores the idea that organizations are political systems and ,any change" equally has an impact on the power relationships within the organization.

Although organisations have to adapt to their environment, they tend to feel comfortable operating within the structure, policies and procedures, which have been formulated to deal with the range of present situations. Organisations, like individuals, can become saturated and thereby, be either unwilling or unable to integrate new and deeper changes, even if these are acknowledged as necessary [5].

High formalisation, centralisation, and stratification built into an organisational structure are often seen as barriers to change [23-26]. Several studies have indicated that successful change efforts were achieved through the informal rather than the formal organisation [19, 27].

Katz and Kahn [28] highlight the narrow focus of change: the interdependencies among organisational elements, such as people, structures, tasks and the information system must be taken into account. De Wit and Meyer [29] mention cultures, that reflect only stability and support rigid thinking through group inertia and closed mindsets, as the cause of resistance. It may be noted here that an organisation's systems of governance are embedded in its ways of thinking, which in turn are reinforced by its systems and processes.

As most studies have shown that employees resist social change more than technical change, the change 
programs which ignore psychological resistance to change are likely to fail, irrespective of the way the new desired attitudes are presented [30].

Jick [5] suggests managers need to rethink resistance to change as a normal part of adaptation, which protects a person's self-integrity. Providing security and rewards is essential to creating a climate in which people will take risks.

Coch \& French [31] were the pioneers in demonstrating that employee participation is the effective approach/strategy for social change. Ever since their work, participatory approaches to change have been the most popular. Kotter and Schlesinger [32] present six strategies for facilitating change and overcoming resistance: employee participation and involvement, education and communication, facilitation and support, negotiation and agreement, manipulation and cooptation and finally explicit and implicit coercion.

In order to find out how theories worked out in western countries fit countries in transition, the author conducted an empirical study in Estonian organisations.

\section{Empirical study in Estonian Organizations}

\subsection{Methodology}

The research reported in this paper is based on a survey of 137 Estonian companies. The companies were selected from various industries, ranging from retail and wholesale, banks and insurance companies, to those in energy and transportation industries. Ninety percent of the companies studied have experienced transformational change [32].

In the research process, interviews about the changes in their organizations were conducted with top managers or with the members of the executive board. In each organization one member of the executive board or board of directors was interviewed. In $33 \%$ of companies the top manager of the company answered the questions. Among members of the executive board or deputy directors $15.5 \%$ were in sales and marketing, $12.2 \%$ specialised in human resources and $6 \%$ in finances. The others were in import-export, information technology, quality control, logistics, product development and other areas. A remaining $31.1 \%$ of deputy directors or board members did not specify their area. Questions about the process of implementing change were open-ended.

\subsection{The process of change}

The steps in the process of change proposed by previous researchers were analysed on the basis of the steps in the most popular model of change process, Kotter's [20] model. Results indicated that $59 \%$ of the respondents mentioned his first step: creating an awareness of the necessity for change. The majority, $76 \%$ of managers, also mentioned the third step: creating vision and strategy. The next most popular group of steps among managers was connected with mobilising commitment, achieving employee support for changes and training employees. Twenty-four percent of respondents formed a coalition, which is Kotter's second step, and $36 \%$ communicated their vision to the employees (Kotter's fourth step). Forty-five percent of all the respondents implemented the sixth step by involving and training their employees. Only $6 \%$ mentioned the fifth stepthe creation of a suitable climate for the implementation of their vision. The least popular activities were connected with the last two steps-only $10 \%$ of the respondents mentioned planning and creating shortterm gains and $21 \%$ had institutionalized changes in the organizational culture.

This shows that the main focus of Estonian managers was on initiating changes with much less attention paid to assessing the process of change and making modifications and consolidating improvements. Although their attention was focused on initiating changes, nobody mentioned having identified any form of resistance.

These results were also analysed according to the size of the company. First, nine groups were formed. As the majority of companies in Estonia have less than 100 employees, we started to group companies after every ten employees: first group from 1 to 10 , second from 11 to 20 and so on. The last groups were from 51 to 100 , from 101 to 500 , from 501 to 1000 and over 1000. Analysis indicated that the groups in the middle,

Table 2. Change process according to size of the company

\begin{tabular}{|lcccccccccc|}
\hline $\begin{array}{l}\text { Number of } \\
\text { employees }\end{array}$ & $\begin{array}{l}\% \\
\text { the } \\
\text { sample }\end{array}$ & $\begin{array}{l}\text { Sense of } \\
\text { urgency }\end{array}$ & $\begin{array}{l}\text { Forming a } \\
\text { coalition }\end{array}$ & $\begin{array}{l}\text { Creating } \\
\text { a vision }\end{array}$ & $\begin{array}{l}\text { Commu- } \\
\text { nicating } \\
\text { the vision }\end{array}$ & $\begin{array}{l}\text { Creating } \\
\text { a suitable } \\
\text { climate }\end{array}$ & $\begin{array}{l}\text { Employee } \\
\text { involvement } \\
\text { and training }\end{array}$ & $\begin{array}{l}\text { Creating } \\
\text { short-term } \\
\text { wins }\end{array}$ & $\begin{array}{l}\text { Institutiona- } \\
\text { lising the new } \\
\text { approaches }\end{array}$ \\
\hline $1-10$ & 9 & $57^{*}$ & $47^{*}$ & $100^{*}$ & $43^{*}$ & $29^{*}$ & $29^{*}$ & 14 & 14 \\
$11-100$ & 51 & $63^{*}$ & 13 & $58^{*}$ & $29^{*}$ & 8 & $61^{*}$ & 19 & 18 \\
$101-$ & 40 & $47^{*}$ & $32^{*}$ & $75^{*}$ & $38^{*}$ & $28^{*}$ & $50^{*}$ & 13 & $25^{*}$ \\
Total & 100 & $56^{*}$ & 24 & $69^{*}$ & $34^{*}$ & 18 & $53^{*}$ & 16 & 21 \\
\hline
\end{tabular}


starting from 11 employees and ending with 100 had similar results (Table 2).

As the results show, three different groups seemed to follow the steps in the process of implementing organisational changes. The symbol ,"” marks steps, which were implemented by more than $25 \%$ of the companies in the group and could be considered as important for these companies.

We can see better results in the smallest and biggest companies, where almost all the steps, excluding creating small wins, were implemented. The smallest companies did not institutionalise changes, but because of the small number of employees it may well be unnecessary to write rules down-the active verbal communication among all members available in companies of this size could replace the need for written documents. We can see the greatest number of problems in medium sized companies - from 11 to 100 employees.

\subsection{Resistance and overcoming resistance to change}

Causes of resistance and difficulties in implementing of change in studies of Estonian companies are shown in Table 3.

The respondents said that resistance to change had appeared on all the levels of their organization. According to $36 \%$ of the respondents, resistance to change mostly originated from inertia in the thinking of employees, $23 \%$ of the respondents found that fear of new and unknown situations caused resistance, 9 $\%$ of them saw employee resistance as a reaction to overly quick and unclear changes and $4 \%$ of the respondents mentioned obstacles in information sharing-information blockades.
The respondents were also asked about the most difficult issues during the implementation of change. It appeared that the biggest difficulty according to 32 $\%$ of the respondents was in unlearning what they had done before, while $24 \%$ of them found that employees did not realise how necessary the changes were for the company. Fourteen percent of the respondents found it difficult to find qualified personnel for the implementation of changes, $12 \%$ mentioned difficulties when merging with different cultures and $6 \%$ pointed out insufficient information and a difference in understanding several issues, probably making it difficult to sustain trust between managers and employees.

Kotters and Schlesinger's [33] six strategies for overcoming resistance were taken as the basis for analysis in this point. Research in Estonian companies indicated, that communication and the education of employees were the most often used strategies in overcoming resistance to change as $85 \%$ of the managers questioned used these strategies. In addition $24 \%$ of the managers mentioned participation and involvement, $21 \%$ used facilitation and support and 15 $\%$ negotiated with their employees. The least used strategies were coercion in $6 \%$ of the cases and manipulation, only used by $2 \%$ of the respondents.

The managers were also asked about what they would do differently in the future. Twenty-two percent of the respondents would plan and prepare changes more carefully and $14 \%$ would pay more attention to establishing goals; another $22 \%$ would explain the essence of the changes to their employees in greater detail and give more information in a more practical way; $16 \%$ of the managers questioned learned the importance of the involvement of employees on every level of the organization from the early stages of the changes; $14 \%$ would practice more teamwork and 5

Table 3. Resistance to change and strategies for overcoming resistance in Estonian organizations

\begin{tabular}{|c|c|c|c|c|c|}
\hline Resistance to change & $\begin{array}{c}\% \text { of } \\
\text { answers }\end{array}$ & The most difficult issues & $\begin{array}{c}\% \text { of } \\
\text { answers }\end{array}$ & $\begin{array}{c}\text { Strategies for } \\
\text { overcoming resistance }\end{array}$ & $\begin{array}{c}\% \text { of } \\
\text { answers }\end{array}$ \\
\hline Inertia in the thinking & $36 \%$ & $\begin{array}{l}\text { To unlearn what they had } \\
\text { done before }\end{array}$ & $32 \%$ & $\begin{array}{ll}\text { Education } & \text { and } \\
\text { communication }\end{array}$ & $85 \%$ \\
\hline Fear of the unknown & $23 \%$ & $\begin{array}{l}\text { To make employees } \\
\text { understand how necessary } \\
\text { the changes are }\end{array}$ & $24 \%$ & $\begin{array}{l}\text { Employee participation } \\
\text { and involvement }\end{array}$ & $24 \%$ \\
\hline $\begin{array}{lll}\text { Unwillingness } & \text { to } & \text { do } \\
\text { additional work } & & \\
\end{array}$ & $15 \%$ & To find qualified personnel & $14 \%$ & $\begin{array}{l}\text { Facilitation } \\
\text { support }\end{array}$ & $21 \%$ \\
\hline Planned redundancies & $10 \%$ & Merging different cultures & $12 \%$ & Negotiation & $15 \%$ \\
\hline $\begin{array}{l}\text { Reaction to overly quick } \\
\text { and unclear changes }\end{array}$ & $9 \%$ & Difference in understanding & $6 \%$ & $\begin{array}{l}\text { Manipulation and co- } \\
\text { optation }\end{array}$ & $6 \%$ \\
\hline Information blockades & $4 \%$ & & & $\begin{array}{l}\text { Explicit and implicit } \\
\text { coercion }\end{array}$ & $2 \%$ \\
\hline
\end{tabular}


$\%$ would consider the human factor more seriously; $4 \%$ would do a preliminary survey among the employees about their attitudes towards the planned changes.

\section{Conclusions and a model for implementing change in Estonian companies}

The survey results indicated that the biggest difficulty during the implementation of change was inertia in the thinking of employees. Employees did not realise how necessary the changes were for the company and it was difficult to them to unlearn what they had done before. There was also fear of the unknown. This may stem from the existence of different ideologies in the Soviet Union and the European Union. Transformation has included all aspects of society, including the political, economic and social system. In the beginning, people did not even know how their new society should look. In totalitarian societies people's choices were constrained because of the use of coercive forms of political and economic control [34]. In contrast, a free market economy with a democratic political system presented people with many choices. This difference at the societal level has also carried through into organisations. Üksvärav [35] found that well developed hierarchies, where people expect answers to problems to be decided by someone higher up, and even managers were inclined to rely on aid and direction from higher authority, was one of the outstanding features of the Soviet era in Estonia. Also, the time that Estonia has had to move from a totalitarian regime to a democratic system has been too short to develop a sufficient level of welfare as the basis for employee self-reliance.

Estonian managers underestimated the resistance to change and the strength of people's attitudes, inherited from the previous socialist system. Especially large problems faced managers of companies with between 10 and 100 employees. These managers had started with small entrepreneurial companies with less than 10 people, where everyday communication was possible with all employees and there was no need for a clear division of labour or special management techniques. This indicates that in Estonia managers still lack competence. This finding supports the view that the syndrome of „management Sovieticus” $[4,36]$ has damaged Estonian management culture more than it is possible to heal in one decade. The current study indicates that managers have learned from the changes they implemented, how important it is to involve employees from every level of the organisation already in the early stages of the change.
Based on the survey results the author proposes a change model for Estonian organisations consisting of four steps. The author of this study divided Lewin's [11] first step into two parts and added emphasis to the need for unlearning past practices and changing attitudes. The new steps in the change model for Estonian companies are: (1) Determining the need for change and unlearning followed by creating a vision; and (2) Determining the obstacles to change and unlearning, followed by gaining the participation of organisational members. These steps are followed by (3) the implementation of unlearning and the implementation of change; and (4) consolidating improvements and institutionalising the change. The change model for Estonian companies is presented in Figure.

During the first step, managers scan the environment and compare the actions and processes in the company with similar activities in leading companies in the same field. This may then lead to recognising the need for organisational change. A vision of the future state of the company should then be created on the basis of these observations and the current resources of the company. At the same time, managers should analyse their assets concerning know-how and then they may recognise the need for new know-how, attitudes and behaviours in the organisation in order to accomplish this new vision. Managers also need to create a vision of the people with the new expertise, attitudes, and behaviours. They should then ascertain how large the gap is between the existing attitudes of employees and the desired attitudes and behaviours. This will help to determine need for unlearning.

During the second step, to determine the force of resistance as an obstacle to change and learning, the manager should conduct force-field analysis. The manager should also be aware of any forces that do not allow the unlearning to take place. In this stage a strategy should be worked out for removing all identified obstacles. As employee participation has been considered as the most popular strategy for overcoming any resistance to change, strategies are developed for gaining employee commitment to the change. One possibility for increasing employee involvement is to encourage employee activity, their willingness to take initiative and their participation in decision-making. Managers should make sure that the employees have really understood the organisation's business objectives and that everything possible is being done to achieve employee commitment to these objectives. This is only possible if employees can see a connection between the company's objectives and their own objectives. The use a collaborative setting of missions and strategies could help. The creation of 

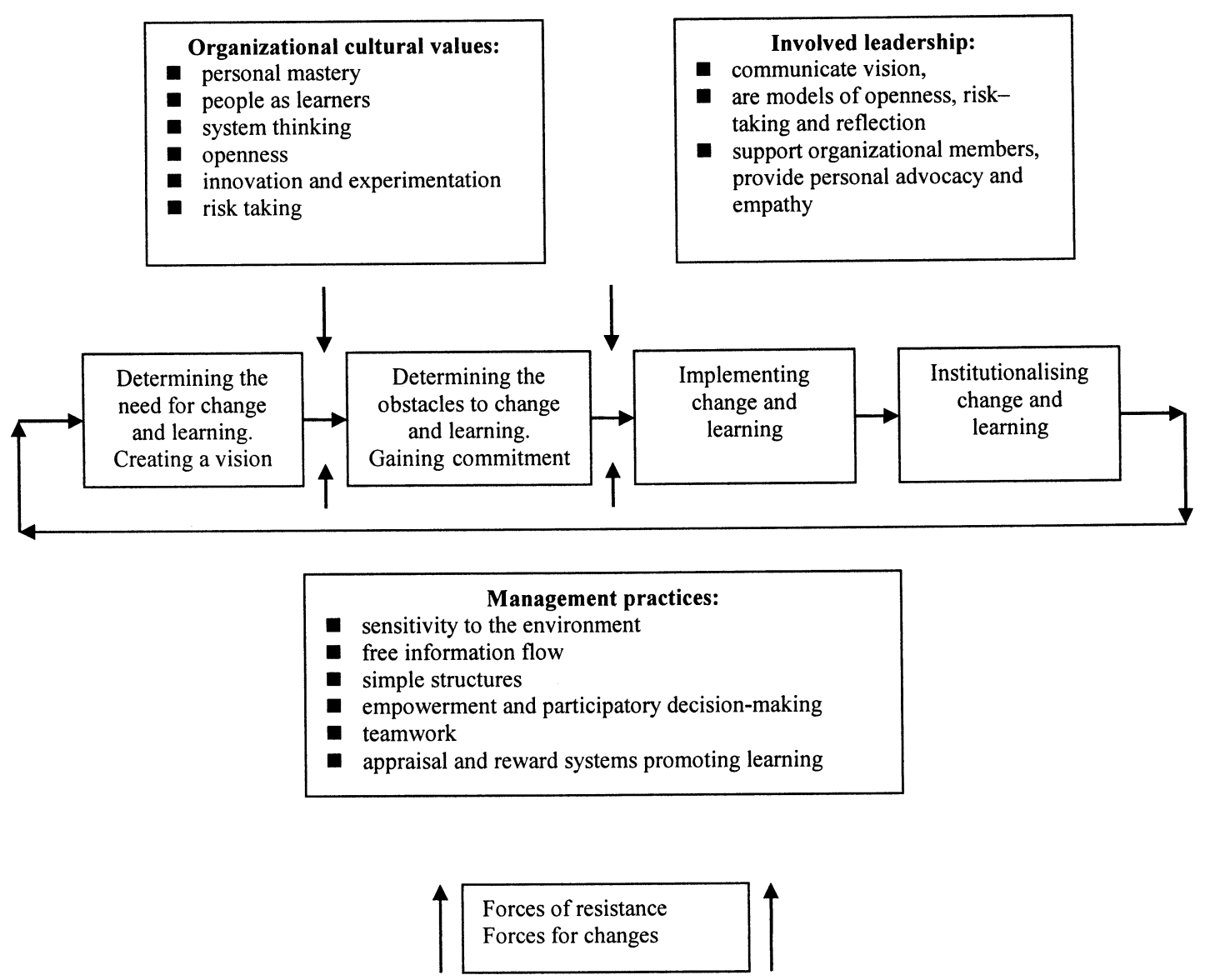

Model of organisational change and learning in Estonian companies

the conditions and motivation for unlearning and learning by creating open minded and positive attitudes toward risk-taking is useful.

The third step, implementing change, is similar to Lewin's second stage. The author has added implementing unlearning. Plans made during the earlier stages are carried out. Changes to the structure, operations and processes are implemented. Employees unlearn old skills and learn new skills and behaviours. Learning by making mistakes takes place. The ability to use collaborative skills and teamwork is very important at this stage. There is a growth of open communication and the willingness among employees to develop themselves. The manager's role here is to support the personal development of employees.

The fourth step is for evaluating the results of the change effort and for consolidating positive results. Successful changes in behaviours and processes are written down as rules and procedures, and changes are institutionalised. Institutionalising learning means storing all the knowledge obtained in the organisation. The information system should enable the storage of knowledge so that after people leave, their knowledge remains within the organisation. It should also make information available to all the people making decisions or conducting analyses. At the same time it should be stated in procedures as well, that these changes are not final-the organisation remains flexible and open to new changes and unlearning and learning have become core activities of the company.

During all four steps of the organisational change process the company's management has a central role. A participatory style of leadership and choosing management practices, which help to create a learning environment, form a great part in the success of the change process.

In conclusion, the survey results indicate that to implement organisational changes more successfully, managers of Estonian companies should turn more of their attention to unlearning habits and thinking patterns that people obtained during the Soviet era in Soviet organisations. This unlearning process and the replacement of these patterns with others more suitable for dynamic organisations in an extremely rapidly changing global environment, is the central issue in the process of change in Estonian post-socialist companies. 


\section{References}

1. Armenakis, A. A. Review of Research on the Change Typology. In: Woodman, R. W., \& Pasmore, W. A. (eds.) Research in Organizational Change and Development, Vol 2, 1988, p. 163194.

2. Beatty, R. W., \& Ulrich, D. O. Re-energizing The Mature Organization. In: Jick, T. D. Managing Change. Cases and Concepts, Irwin, 1993, p. 60-74.

3. Alas, R. Employee's attitudes in countries with different past, Journal of Business Economics and Management, 3(1), 2003, p. $45-52$.

4. Liuhto, K. The Organisational and Managerial Transformation in Turbulent Business Environments - Managers' views on the transition of their enterprise in some of the European former Soviet republics in the 1990's. Publications of the Turku School of Economics and Business Administration, Series A-9, 1999.

5. Jick, T. D. Managing Change. Cases and Concepts. Irwin, 1993.

6. Pettigrew, A. M., \& Whipp, R. Managing Change for Competitive Success. Oxford and Chambridge, MA: Blackwell. 1991.

7. Van de Ven, A. H., \& Poole, M. S. Explaining Development and Change in Organizations. Academy of Management Journal Review, 20, 1995, p. 510-540.

8. Bennis, W. G. Changing Organizations. Essays on the Development and Evolution of Human Organization. McGrawHill. 1966.

9. Armenakis, A. A., \& Bedeian, A., G. Organizational Change: A Review of Theory and Research in the 1990s', Journal of Management 25, 1999, p. 293-315.

10. Porras, J. I., \& Robertson, P. J. Organizational Development Theory. A Typology and Evaluation. In: Woodman, R. W., \& Pasmore, W. A. (eds.) Research in Organizational Change and Development, 1, 1987, p. 1-57.

11. Lewin, K. Changing as Three Steps: Unfreezing, Moving, and Freezing of Group Standards. In French, W. L., Bell, C. H. Jr., Zawacki, R. A. (eds.): Organizational Development. Theory, Practice, and Research. Third edition. Irwin, 1989, p. 87.

12. Foster, M. The Historical Perspective. In: McLennan, R. (Ed) Managing Organizational Change. Prentice Hall, 1989, p. 3438.

13. Mohrman, S.A., \& Cummings, T. G. Self-Designing Organization: Learning How to Create High Performance. Addison-Wesley Publication Company Inc. 1989.

14. Tichy, N., \& Devanna, M. (1986) The Transformational Leader. New York: John Wiley \& Sons.

15. Cummings T. G.; Worley, C. G. Organization Development and Change, 6th ed. South-Western College Publishing. 1997.

16. Judson, A. Changing Behavior in Organizations: Minimizing Resistance to Change. Cambridge, MA: Basil Blackwell. 1991.

17. Goss, T.; Pascale, R.; Athos, A. The Reinvention Roller Coaster: Risking the Present for a Powerful Future. A Harvard Business Review Paperback, 1998, p. 83-112.

18. Greiner, L. E. Evolution and Revolution as Organizations Grow. In: Harvard Business Review On Management. Harper \& Row Publishers, 1975, p. 636-649.

19. Beer, M.; Eisenstat, R.; Spector, B. Why Change Programs Don't Produce Change. Harvard Business Review, NovemberDecember, 1996, p. 158-166.

20. Kotter, J. P. Leading Change: Why Transformation Efforts Fail. Harvard Business Review on Change. A Harvard Business Review Paperback, 1998, p. 1-21.

21. Galpin, T. The Human Side of Change: A Practical Guide to Organization Redesign. San Francisco: Jossey-Bass, 1996.
22. Lawrence, P. R. How to Deal with Resistance to Change. Harvard Business Review On Management. Harper \& Row Publishers, 1975, p. 390-408.

23. Evers, F. T., Bohlen, J. M., Warren, R. D. The Relationship of Selected Size and Structure Indicators in Economic Organizations. Administrative Science Quarterly, 21, 1976, p. 326-342.

24. Hage, J., Aiken, H. Social Change in Complex Organizations. New York: Random House. 1970.

25. Quinn, R. E. Beyond Rational Management: Mastering the Paradoxes and Competing Demands of High Performance. San Francisco: Jossey-Bass. 1988.

26. Burns, T., Stalker, G. M. The Management of Innovation. London: Tavistock Publications. 1961.

27. Woodward, J. Industrial Organization: Theory and Practice. Second edition. Oxford University Press. 1980.

28. Katz, D., Kahn, R. L. The Social Psychology of Organizations. Second edition. New York: Wiley. 1978.

29. DeWit, B., \& Meyer, R. Strategy: Process, Content, Context. An International Perspective. Second edition. London: International Thomson Business Press. 1998.

30. Schein, E. H. Management Development as a Process of Influence. In: Richards, M. D. (ed.) Readings in Management. South-Western Publishing Co, 1986, p. 602-618.

31. Coch, L., French, J. P. Overcoming Resistance to Change. Human Relation, 1, 1948, p. 512-523.

32. Alas, R., \& Sharifi, S. (2002) Organizational Learning and Resistance to Change in Estonian Companies. Human Resource Development International, Vol. 5 (3): 313-331.

33. Kotter, J. P., Schlesinger, L. A. Choosing Strategies for Change. Harvard Business Review, March-April, 1979, p. 106-114.

34. Eagly, A. H., and Chaiken, S. The Psychology of Attitudes, Harcourt College Publishers. 1993.

35. Üksvärav, R. Management Culture in Estonia: Past and Present Features, in Suominen, A. (Ed.) Searching for the Boundaries of Business Culture, Publications of the Turku School of Economics and Business Administration. Series C-1, 2001, p. 103-120.

36. Nurmi, R., and Üksvärav, R. Estonia and Finland: Culture and Management, a Conceptual Presentation. Publications of the Turku School of Economics and Business Administration. Series A-9. 1994. 